\title{
Preservice Teachers' Self-Efficacy in the Teaching of Science at Basic Schools in Ghana
}

\author{
Isaac S. Coffie* Nutifafa G. Doe \\ Department of Science, Wiawso College of Education, Ghana
}

\begin{abstract}
Many researchers emphasize the need to look at teacher self-efficacy in preservice teacher preparation and training for the teaching profession. The purpose of this study was to explore science teachers' efficacy beliefs of preservice teachers who are enrolled in general programme and those enrolled in science programme at a college of education in Ghana. Data for the study were collected from a total number of 227 preservice teachers using Science Teaching Efficacy Belief Instrument (STEB-B). Data were analysed using both descriptive and inferential statistics specifically mean and standard deviation and t-test. The results indicated that preservice teachers had high science teaching efficacy however, those who are enrolled in science programme were efficacious than their counterpart in the general programme. Also there was a statistically significant difference in gender on the preservice teachers' science teaching efficacy beliefs.
\end{abstract}

Keywords: Self-efficacy, preservice teacher, science teaching, science programme, general programme.

DOI: $10.7176 / \mathrm{JEP} / 10-22-12$

Publication date: August $31^{\text {st }} 2019$

\section{Introduction}

Science education is regarded as an important tool for the development of any country. This is because science serves as the basis of technology. Science education in primary schools aims at showing the way children can understand and investigate their surroundings and the universe (Government of Ireland, 1999). It is therefore not surprising that the Ghana Education Service (GES) and the Ministry of Education maintains that science should be a compulsory core subject for all pre-tertiary students. There are generally two main goals of science education in Ghana. The first is to inculcate scientific literacy and culture for all so that people can make informed choices in their personal lives. The second goal is to produce competent professionals in the various scientific disciplines who can carry out research and development at the highest level (Curriculum Research and Development Division, CRDD, 2007).

The achievement of these goals will be mostly dependent on science teachers who have high self-efficacy especially those at the basic level of education to be able to lay a strong foundation for the study of science. Many teacher educators take for granted that once students complete science content and methods courses they will be able to function successfully in science classrooms (Ramey-Grassert \& Shroyer, 1992). However, Ramey-Grassert and Shroyer believe that for many basic school teachers this is not the case. There is a challenge to produce teachers who have the confidence and the competence to teach science as basic or elementary level (Mulholland, Dorman \& Odgers, 2004) as studies have shown that many elementary teachers do not feel prepared and comfortable in teaching science (Howitt, 2007; Westerback, 2006).

A teacher will not be efficient on the job if he/she lacks (or has low) self-efficacy (Uzen, Ozkili \&Senturk, 2010). Many researchers therefore emphasize the need to look at teacher self-efficacy in preservice teacher preparation (Czerniak \& Chiarelott, 1990; Enochs \& Riggs, 1990; Ramey-Gassert \& Shroyer, 1992). Even though several studies have been carried out in finding the self-efficacy of preservice teachers (Arigbabu \& Oludipe, 2010; Norris, Morris \& Lummis, 2018) the subject and situation specific nature of teachers' self-efficacy makes it timely and relevant (Ramey-Gassert \& Shroyer, 1992) that a study be carried in the Ghanaian context where we train both specialist and generalist basic education science teachers. This is because it appears no such study has been carried out to find the science teaching self-efficacy of both the specialist trained preservice science teacher and the generalist trained preservice teacher. This research therefore seeks to explore the preservice teachers' efficacy in the teaching of science subject at the basic schools in Ghana.

The study was guided by the following research question and hypotheses.

\section{Research Question}

What is the science teaching efficacy of the preservice teachers?

\section{Research Hypotheses}

Ho: $_{0}$ There is no statistically significant difference in science teaching efficacy between the pre-service teachers who are enrolled in the science programme and those in the general programme.

$\mathbf{H}_{0}$ : There is no statistically significant difference in science teaching efficacy between male and female pre-service teachers. 


\section{Science Teacher Efficacy}

Ramey-Gasser and Shroyer (1992) attribute some of the challenges in science education such as poor attitudes toward science and poor teaching approaches used in science teaching to low science teaching self-efficacy. Czerniak and Chiarelott (1990) contend that "science anxiety and efficacy and strategies that reduce anxiety and increase efficacy are worthy of attention in teacher education if we wish to improve the quality, quantity, and success of science curriculum and instruction" (p. 5). To produce science teachers who can bridge the achievement gaps in science education, science teacher educators must identify practices that influences preservice teacher selfefficacy (Cone 2009). This idea is supported by Ramey-Gassert and Shroyer (1992) who also contend that to bring about improvement in the ability, effectiveness and feeling of success in elementary teacher, issues of self-efficacy must be taken serious by science educators. Ramey-Gassrt and Shroyer (1992) defined science teaching efficacy as "the belief or confidence that a teacher has in his or her ability to teach science effectively" (p.27). Elementary or basic science teaching self-efficacy is regarded as an important issue in developing quality teaching. This is because the type of experience teachers gain in their training are valuable for increasing their self-efficacy to teach science (Gunning \& Mensah, 2011).

Many preservice elementary education teachers have low interest and proficiency in science which can undermine their teaching of the subject (Cervato \& Kerton, 2017). Science teachers tend to teach as they have been taught and it is only when teachers have strong science teaching self- efficacy that they will to try new methods of teaching science (Ramey-Gassert \& Shroyer, 1992). Study has established a relationship between science teachers' self -efficacy and their use of new approaches in science teaching (Temiz \& Topcu, 2013). In a study to explore the relationship between preservice teachers' self-efficacy beliefs and ability to use constructivist based teaching practice, Temiz and Topcu found that the teachers' constructivist based teaching practice was positively correlated with their efficacy beliefs. They concluded that teachers with high efficacy tend to employ the constructivist approach when teaching while the other teachers with low efficacy tend to use the traditional lecture method in teaching.

A measure of science teaching efficacy can predict the teaching success of preservice teachers and the extent to which they can act positively to impact on student achievement in science in the future (Cantrell, Young \& Moore, 2003). They posit that preservice elementary teachers who are prepared to teach science at the basic schools have broad range of efficacy belief about their success as future science teachers.

\section{Theoretical framework}

Teacher efficacy has become an important topic in teacher education in the past 25 years (Cantrell et al., 2003). The concept of self-efficacy is attributed the work of Bandura (1977) who defined self-efficacy as "beliefs in one's capabilities to organize and execute the courses of action required to produce given attainments" (Bandura, 1997, p. 3). Bandura believed that the choice of activities people engages in, the effort they expend on them and their persistence in doing those activities are influenced by their perceived self-efficacy which he defined as, "people's judgements of their capabilities to organize and execute courses of action required to attain designated types of performances" (Bandura, 1986, p. 3). He identified that self-efficacy is made up of two cognitive constructs: (1) personal self-efficacy and (2) outcome expectancy. He defined Personal self-efficacy as "judgments about how well one can organize and execute courses of action required to deal with prospective situations that contain ambiguous, unpredictable, and often stressful elements" (Bandura, 1977, p. 201) and outcome expectancy as "a person's estimate that a given behaviour will lead to certain outcomes" (p.201). Self- efficacy affects the choice and direction of many human behaviour (Shunk, 1989) and depends on the capacity of the individual to plan and implement actions (Khourey-Bowers \& Simonis, 2004). To Bandura, self-efficacy is developed through four main sources: mastery experiences; vicarious experiences; verbal persuasion; and physiological and affective states (Gunning \& Mensah, 2011). The most important factor of an individual self-efficacy is performance accomplishment (Huang, 2013). Self-efficacy is based on self-perceptions with regards to particular behaviours and it is therefore considered to be situation or context specific and task dependent (Giles, Byrd \& Bendolph, 2016; Huang, 2013).

One factor that is often cited as consistent predictor of teacher success is teacher self- efficacy (Scharmann, \& Hampton, 1995). Teacher's self- efficacy is a predictor of teachers' practice and student outcomes (Graham, Harris, Fink \& MacArthur, 2001; Shunk, 1989) since it influences teachers' classroom management, methods of teaching and increases students' motivation to learn and succeed (Uzen et al., 2010). Teachers self-efficacy influences both the teacher and the students' behaviour (Shunk, 1989). Teacher efficacy has been associated with many educational outcomes such as student motivation and student achievement, percent of project goals achieved, amount of teacher change, continuation of both project methods and materials, and improved student performance (Ramey-Gassert \& Shroyer, 1992: Tschannen-Moran, Hoy \& Hoy, 1998). It is an important motivational construct for achieving success (Huang, 2013).

Bandura (1986) believed that individuals with high self-efficacy are high achievers. Teachers with high level of self-efficacy are able to endure job stress and can practice good classroom management (Gurcay, 2015). 
Teachers with high level of efficacy have the believe that they can control student achievement and motivation (Tschannen- Moran et al., 1998). They do this by challenging and helping students to succeed in the classroom even those who may be have learning difficulties (Shunk, 1989). Gibson and Dembo (1984) also posit ".... teachers who believe student learning can be influenced by effective teaching (outcome expectancy beliefs) and who also have confidence in their own teaching abilities (self-efficacy beliefs) should persist longer, provide a greater academic focus in the classroom, and exhibit different types of feedback than teachers who have lower expectations concerning their ability to influence student learning" (p. 570). Great efficacy therefore produces great effort and persistence which in turn lead to better performance (Tschannen-Moran et al., 1998).

On the other hand, teachers with low sense of efficacy have doubts about their ability to influence students learning and will not plan activities beyond their abilities. They may easily give up in helping students having learning difficulties and will not expend additional effort to find materials, or think of better ways to teach content (Shunk, 1989). Low efficacy leads to less effort and persistence which produces poor teaching outcomes (Tschannen- Moran et al., 1998).

\section{Methods}

The study was conducted in a college of education in Ghana where two groups of preservice teachers are prepared to teach science at the basic schools. The first group are generalist teachers who take some science courses so that they can teach science at the basic school. The second group consist of preservice teachers who specially trained for only science teaching at the basic school. The participants for the study were made up of 227 preservice teachers. Among this number, 53 representing $23 \%$ of the sample were preservice teachers who are enrolled in science programme while the remaining 174 constituting $77 \%$ of the sample for the study are enrolled in general programme. The total sample was also made up 139 males and 88 females forming $61 \%$ and $39 \%$ of the sample respectively. Descriptive cross sectional survey design was used for the study.

The instrument used for the study was Science Teaching Efficacy Belief Instrument (STEBI) form B which was designed by Enochs and Riggs (1990) to measure the self-efficacy of preservice basic/elementary school science teachers. It consists of 23 items in a Likert-type scale format with response categorization of "Strongly Agree" "Agree" "Uncertain" "Disagree" and "Strongly Disagree". In this study the response categorization "Uncertain" was changed to "Nuetral" to fit the context of the study.

The instrument consists of two scales measuring Personal Science Teaching Efficacy (PSTE) and Science Teaching Outcome Expectancy (STOE). Personal Science Teaching Efficacy (PSTE) is a teacher's belief regarding his or her own ability to teach science effectively (Enochs \& Riggs, 1990). The PSTE scale has 13 items with five positive worded statements and a reliability coefficient of 0.90 (Enochs \& Riggs, 1990). However, in this study one of the items was modified into a positive statement to fit our local context. The STOE subscale also had 10 items with seven positive statements and a reliability co-efficient of 0.76 (Enochs \& Riggs, 1990). The responses were scored as follows: strongly agree was given five points on the scale, agree was given four points and neutral, disagree and strongly disagree were awarded three, two and one points respectively to give a minimum score of 23 and a maximum score of 115 after all negatively worded statements had been reverse coded.

\section{Results}

The purpose of the study was to explore the science teaching efficacy belief of preservice by comparing the science self-efficacy of the preservice teachers who are enrolled in Science programme and those enrolled in General programme. A test for normality was done by inspecting a histogram graph and Levene test for equality of variance which was significant at 0.791 . The result of the descriptive statistics is shown in Table 1.

Table 1: Result of Descriptive Statistics of the Preservice Teachers' Science Teaching Efficacy

\begin{tabular}{lll}
\hline Variable & Composite Mean & Standard deviation \\
\hline Science teaching efficacy & 79.22 & 11.42 \\
\hline
\end{tabular}

From Table 1, it can be seen that the overall mean score of science teaching efficacy belief of the preservice teachers was found to be 79.22 with a standard deviation of (11.42).

An independent-samples t-test was conducted to compare the science teaching efficacy mean scores between the preservice teacher who do the general programme and those whose who do the science programme. The result is presented in Table 2 .

Table 2- Independent Sample t-test of Teaching Efficacy Based Programme

\begin{tabular}{lllllll}
\hline Group & $\mathrm{N}$ & Mean & SD & t & df & p-value \\
\hline Science & 53 & 3.76 & 0.39 & 3.923 & 226 & 0.001 \\
General & 174 & 3.51 & 0.41 & & \\
\hline \multicolumn{7}{c}{$\left(\eta^{2}=0.06\right)$} \\
\hline
\end{tabular}

From Table 2, it can be seen that there was a statistically significant difference for the independent sample ttest for equality of variance; $t(226)=3.923, p=0.001$, two-tailed). The magnitude of the difference in the means was small $\left(\eta^{2}=0.06\right)$. This implies that only $6 \%$ of the total variance in the science teaching efficacy was explained 
by programme.

Another independent-samples t-test was conducted to compare the science teaching efficacy mean scores between male and females preservice teachers with result shown in Table 3.

Table 3-Independent Sample t-test of Teaching Efficacy Based on Gender

\begin{tabular}{lllllll}
\hline Group & $\mathrm{N}$ & Mean & SD & t & df & p-value \\
\hline Male & 139 & 3.62 & 0.39 & 2.453 & 226 & 0.001 \\
Female & 88 & 3.49 & 0.43 & & & \\
\hline \multicolumn{7}{c}{$\left(\Pi^{2}=0.03\right)$} \\
\hline
\end{tabular}

The result from Table 3 indicates that there was a statistically significant difference between males and female preservice teacher; $t(226)=2.453, p=0.015$, two-tailed). The magnitude of the difference in the means was small $\left(\Pi^{2}=0.03\right)$. This implies that only $3 \%$ of the total variance in the science teaching efficacy was explained by gender.

\section{Discussion}

Considering that the maximum and minimum scores that can be obtained on the STEBI 115 and 23 respectively with 69 as the midpoint, a score above the mid can be regarded as high. Therefore, the results indicate that the science teaching efficacy of the preservice teachers is high. The high science teaching efficacy belief of the preservice teachers shows that they have the confidence to teach science which can increase students' motivation and achievement

It was found that there was a statistically significant difference in the science teaching efficacy belief between the preservice teachers who offer science programme and the those who offer general programme. The preservice teachers who offer the science programme were more efficacious in teaching science that those who offer the general programme. This can be explained in terms of the numbers of science courses taken by the preservice teachers as a study has establish a positive relation between teachers' efficacy beliefs and the number of science courses taken (Mulholland et al., 2004)). Those who do the science programme take in more science content courses than those in the general programme and content knowledge plays a very crucial role in teacher's science teaching efficacy. Strong science content knowledge together with appropriate use of teaching methods are the main pillars of efficacious science teaching. When teachers have strong content and pedagogical knowledge, their self-efficacy belief increases while their anxiety levels decrease (Czerniak \& Chiarelott, 1990). This could explain the high science teaching efficacy of the preservice teachers who are enrolled in the science programme.

The result indicated that there was a significant difference in science teaching efficacy belief of the preservice teachers in terms of their gender. The result is in support of the findings of some studies that found difference in science teaching efficacy based on gender (Riggs, 1991; Riggs and Enochs 1990). However, the result is a direct contradiction of several studies that found no significant effect on the self -efficacy of teachers in terms of their gender (Mulholland et al., 2004; Savasci- Acikalin, 2014; Uzen et al. 2010). Riggs (1991) has attributed the higher efficacy of male teachers in science teaching to the higher expectation placed on them as they are mostly assigned the role of science coordinators which may could lead to the male teachers believing in themselves as expert science teachers.

\section{Conclusion}

This study has shown that preservice teachers enrolled in science programme and those enrolled in general programme both have high science teaching efficacy beliefs. This implies that the preservice teachers have high confidence which will go a long way to positively influence the teaching and learning of science at the basic school level. The preservice teachers are therefore expected to exert great effort and persistence in their classroom which will in turn lead to good performance in science by the students at basic level of education in Ghana.

The difference is science teaching efficacy in gender and programmes implies that there will be slight variation in the confidence level between the male and female preservice teachers and those who do general programme and science programme. This means there will not be uniformity in implementing classroom practices which are believe to improve student performance in science at the basic school. It is therefore recommended that pragmatic programmes such as peer teaching, field experiences and self-evaluation of microteaching which are believed to improve science efficacy (Enochs \& Riggs, 1990) should be organized for female preservice teachers and those who offer the general programme to improve their science teaching efficacy so that they can be at par with their male counterparts and those who do the science programme.

\section{Limitation of the study}

The main limitation of the study is that the result cannot be generalized because the population is from just a single college.

\section{References}

Arigbabu, A. A. \& Oludipe, D. I. (2010). Perceived efficacy beliefs of prospective Nigerian science teachers. 
Journal of Science Education and Technology,19(1), 27-31. https://www.jstor.org/stable/20627744

Bandura, A. (1977). Self-efficacy: Toward a unifying theory of behavioral change. Psychological Review, 84, 191-215. http://dx.doi.org/10.1037/0033-295X.84.2.191.

Bandura, A. (1986). Social Foundations of Thought and Action: A Social Cognitive Theory, Prentice-Hall, Englewood Cliffs, New Jersey.

Bandura, A. (1997). Self-efficacy: The exercise of control. New York, NY: W.H. Freeman.

Cantrell, P. Young, S., \& Moore, A. (2003). Factors affecting science teaching efficacy of preservice elementary teachers. Journal of Science Teacher Education, 14(3), 177-192.

Cervato, C. \& Kerton, C. (2017). Improving the science teaching self-efficacy of preservice elementary teachers: A multiyear study of a hybrid geoscience course. Journal of College Science Teaching,47(2), 83-91.

Cone, N. (2009). Preservice elementary teachers' self-efficacy beliefs about equitable science teaching: Does service learning make a difference? Journal of Elementary Science Education, 21, (2), 25-34.

Curriculum Research and Development Division, CRDD (2007). Integrated science syllabus for Junior High School, Accra, Ministry of Education

Czerniak, C., \& Chiarelott, L. (1990). Teacher education for effective instruction: A social cognitive perspective. Journal of Teacher Education, 49-58.

Enochs, L.G., \& Riggs, I.M. (1990). Further development of an elementary science teaching efficacy belief instrument: A preservice elementary scale. School Science and Mathematics, 90(8), 694-706.

Gibson, S. \& Dembo, M. (1984). Teacher Efficacy: A construct validity. Journal of Educational Psychology, 76, 569-82.

Giles, R. M., Byrd, K. O., \& Bendolph, A. (2016). An investigation of elementary preservice teachers' self-efficacy for teaching mathematics. Cogent education,3, 1-11. http://dx.doi.org/10.1080/2331186X.2016.1160523.

Government of Ireland (1999). Primary curriculum: Science. Dublin: The Stationery Office

Graham, S., Harris, K. R., Fink, B., \& Macarthur, C. A. (2001). Teacher efficacy in writing: A construct validity with primary grade teachers. Scientific Studies of Reading, 5(2), 177-202.

Gunning, A. M., \& Mensah, F. M. (2011). Preservice elementary teachers' development of self-efficacy and confidence to teach science: A case study. Journal of Science Teacher Education, 22(2), 171-185. doi:10.1007/s10972-010-9198-8.

Gurcay, D. (2015). Preservice physics teachers' beliefs regarding their teacher efficacy and classroom management. Procedia - Social and Behavioral Sciences, 197, 1101-1106.

Howitt, C. (2007). Preservice elementary teachers' perceptions of factors in holistic methods course influencing their confidence in teaching science. Research in Science Education, 37, 41-58.

Huang, C. (2013). Gender differences in academic self-efficacy: a meta-analysis. European Journal of Psychology of Education, 28(1) 1-35.

Khourey-Bowers, C \& Simonis, D. G. (2003). Longitudinal study of middle grades chemistry professional development: Enhancement of personal science teaching self-efficacy and outcome expectancy. Journal of Science Teacher Education, 15(3), 175-195.

Mulholland, J., Dorman, J. P., \& Odgers, B. M. (2004). Assessment of science teaching efficacy of preservice teachers in an Australian university. Journal of Science Teacher Education, 75(4), 313-331.

Norris, C. M., Morris, J. E., \& Lummis, G. W. (2018). Preservice teachers' self-efficacy to teach primary science based on 'science learner' typology. International Journal of Science Education, 40(18), 2292-2308. https://doi.org/10.1080/09500693.2018.1528645.

Ramey-Gassert, L. \& Shroyer, M. G. (1992). Enhancing science teaching self-efficacy in preservice elementary teachers. Journal of Elementary Science Education,4(1), 26-34.

Riggs, I. M. (1991). Gender differences in elementary science teacher self-efficacy. Paper presented at the American Education Research Association, Chicago, IL.

Riggs, I.M., \& Enochs, L.G. (1990). Toward the development of an elementary teacher's science teaching efficacy belief instrument. Science Education, 74(6), 625-637.

Savasci-Acikalin, F. (2014) A study of pre-service teachers' science teaching efficacy beliefs during the elementary science laboratory course. Procedia - Social and Behavioral Sciences, 141, 221-226. doi: 10.1016/j.sbspro.2014.05.038.

Scharmann, L.C. \& Hampton, C.M. O. (1995). Cooperative learning and preservice elementary teacher science self-efficacy. Journal of Science Teacher Education, 6(3), 125-133.

Schunk, D. H. (1989). Self-efficacy and achievement behaviors. Educational Psychology Review, 1(3), 173-208

Skaalvik, E. M., \& Skaalvik, S. (2007). Dimensions of teacher self-efficacy and relations with strain factors, perceived collective teacher efficacy, and teacher burnout. Journal of Educational Psychology, 99 (3), 611625.

Tschannen-Moran, M. Hoy, A. W. \& Hoy, K. W. (1998). Teacher Efficacy: Its Meaning and Measure. Review of Educational Research,68(2), 202-248. 
Temiz, T. \& Topcu, M. S. (2013). Preservice teachers' teacher efficacy beliefs and constructivist-based teaching practice. European Journal of Psychology of Education, 28, (4), 1435-1452.

Uzun, A., Ozkilic, R. \& Senturk, A. (2010). A case study: Analysis of teacher self-efficacy of teacher candidates. Procedia Social and Behavioral Sciences,2,5018-502. doi:10.1016/j.sbspro.2010.03.813.

Westerback, M. E. (2006). Studies on anxiety about teaching science in preservice elementary teachers. Journal of Research in Science Teaching, 21(9), 937-950. 